University of Nebraska - Lincoln

DigitalCommons@University of Nebraska - Lincoln

1957

\title{
Gyrodactylus eucaliae n. sp. (Trematoda: Monogenea) from the Brook Stickleback, Eucalia inconstans*
}

\author{
Glenn L. Hoffman \\ US Fish and Wildlife Service \\ Francis M. Ikezaki \\ University of North Dakota
}

Follow this and additional works at: https://digitalcommons.unl.edu/usfwspubs

Part of the Aquaculture and Fisheries Commons

Hoffman, Glenn L. and Ikezaki, Francis M., "Gyrodactylus eucaliae n. sp. (Trematoda: Monogenea) from the Brook Stickleback, Eucalia inconstans*" (1957). US Fish \& Wildlife Publications. 96.

https://digitalcommons.unl.edu/usfwspubs/96

This Article is brought to you for free and open access by the US Fish \& Wildlife Service at DigitalCommons@University of Nebraska - Lincoln. It has been accepted for inclusion in US Fish \& Wildlife Publications by an authorized administrator of DigitalCommons@University of Nebraska - Lincoln. 


\title{
GYRODACTYLUS EUCALIAE N. SP. (TREMATODA: MONOGENEA) FROM THE BROOK STICKLEBACK, EUCALIA INCONSTANS*
}

\author{
Francis M. Ikezaki and Glenn L. Hoffman \\ Bacteriology Department, University of North Dakota, Grand Forks, North Dakota
}

A new species of Gyrodactylus was observed on the skin, gills, and fins of the brook stickleback from the English Coulee, Grand Forks, North Dakota during the summers of 1953-1955. Host-specificity is usually striking in the monogenetic trematodes and since this parasite was not observed on any other species of fish from this body of water or the nearby Turtle River, it was studied in detail and is here described as a new species, G. eucaliae.

Ether chloretone, chloroform, or menthol at $0.5 \%$, or urethane or nembutal at 0.1 to $0.5 \%$, in aqueous solution, were used in recovering the intact worms from the host. The best solutions proved to be $0.5 \%$ urethane and $0.5 \%$ nembutal. One is cautioned concerning the carcinogenic properties of urethane (Wood, 1956). A convenient field method of collecting the parasites in large numbers consisted of placing the fish in a bottle of $0.5 \%$ nembutal or urethane; the parasites left the host within 3 to 5 minutes and the hosts were discarded ; the fish survived about 5 minutes. Parasites so obtained remained suitable for study for several hours. They were concentrated by sedimentation and fixed in hot $5 \%$ glycerine- $5 \%$ formalin solution. Living worms were studied without the use of anesthetics but were freed from dead fish under refrigeration. The anchors and marginal hooklets were found to be anisotropic with polarized light. The armature was studied in part by allowing the soft parts of the worm to decompose under a vaseline-sealed coverslip and it was found that $16 \% \mathrm{KOH}$ dissolved away the anchors, but not the ventral bar, dorsal bar, or the haptoral shield; this aided in observation of the haptoral armature.

Killed worms were affixed to slides with Haupt's Adhesive (Hargis, 1952) or PVA fixative-adhesive (Hoffman, 1954) and then were stained with coelestin blue B, (Demke, 1952), Semichon's carmine, borax carmine, Harris' hematoxylin, picro-carmine, chlorazol black E, and silver impregnation (Arcadi, 1948). They were dehydrated in cellosolve, cleared in xylol, and mounted in permount. The hooks were most consistently stained selectively with picro-carmine. Both chlorazol black $\mathrm{E}$ and Simichon's carmine were selective in staining the dorsal bar, the ventral bar, and haptoral shield in 10 minutes. Arcadi's silver impregnation method was found to be best for the head organ; it also gave selective staining for the ventral bar, dorsal bar, haptoral shield, and the testis. All measurements are in millimeters and based on 10 specimens except where indicated otherwise.

\section{Gyrodactylus eucaliae n. sp.}

Description: The body is small, cylindrical and fusiform $0.445(0.387-0.590)$ by $0.088(0.066-$ 0.127 ) (Fig. 1). Cuticle thin and smooth. Opisthohaptor, $0.073-0.09$ by $0.083-0.110$, a concavoconvex disc opening ventro-posteriorly; armed with 2 anchors, 2 bars, haptoral shield, and 16 marginal hooklets. Anchors moderately stout, $0.069(0.067-0.071)$ from base to point of greatest curvature and $0.048(0.045-0.051)$ from base to the anchor point with slightly curved roots

Received for publication February 20, 1957.

* This study was undertaken in partial fulfillment of the requirements for the M.S. degree by the senior author (1955). This species was described as G. incisura in his thesis. 
and strongly recurved tips (Fig. 1, 2) ; a "split" 0.044 long and 0.002 at the widest can be seen laterally in some specimens. Ventral bar, 0.026 to 0.031 by 0.007 , relatively stout and gently curved. Dorsal bar delicate, $0.018-0.034$ by 0.002 , with a notch at the midpoint of the posterior edge. Marginal hooklets $0.046(0.041-0.049)$ long with long thin shafts with a small proximal bulb (Fig. 2). Haptoral shield, $0.018-0.02$ by $0.017-0.019$, thin and always present; it is not an

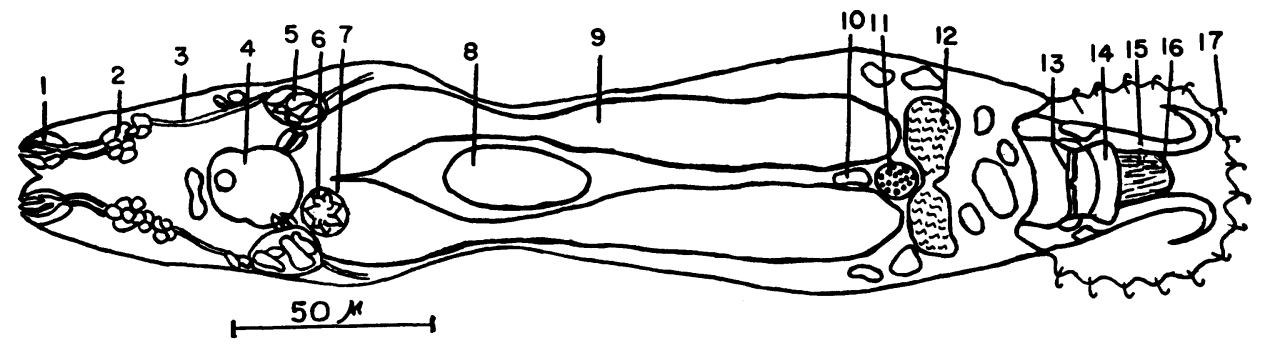

Figure 1. Composite drawnig of Gyrodactylus eucaliae n. sp.

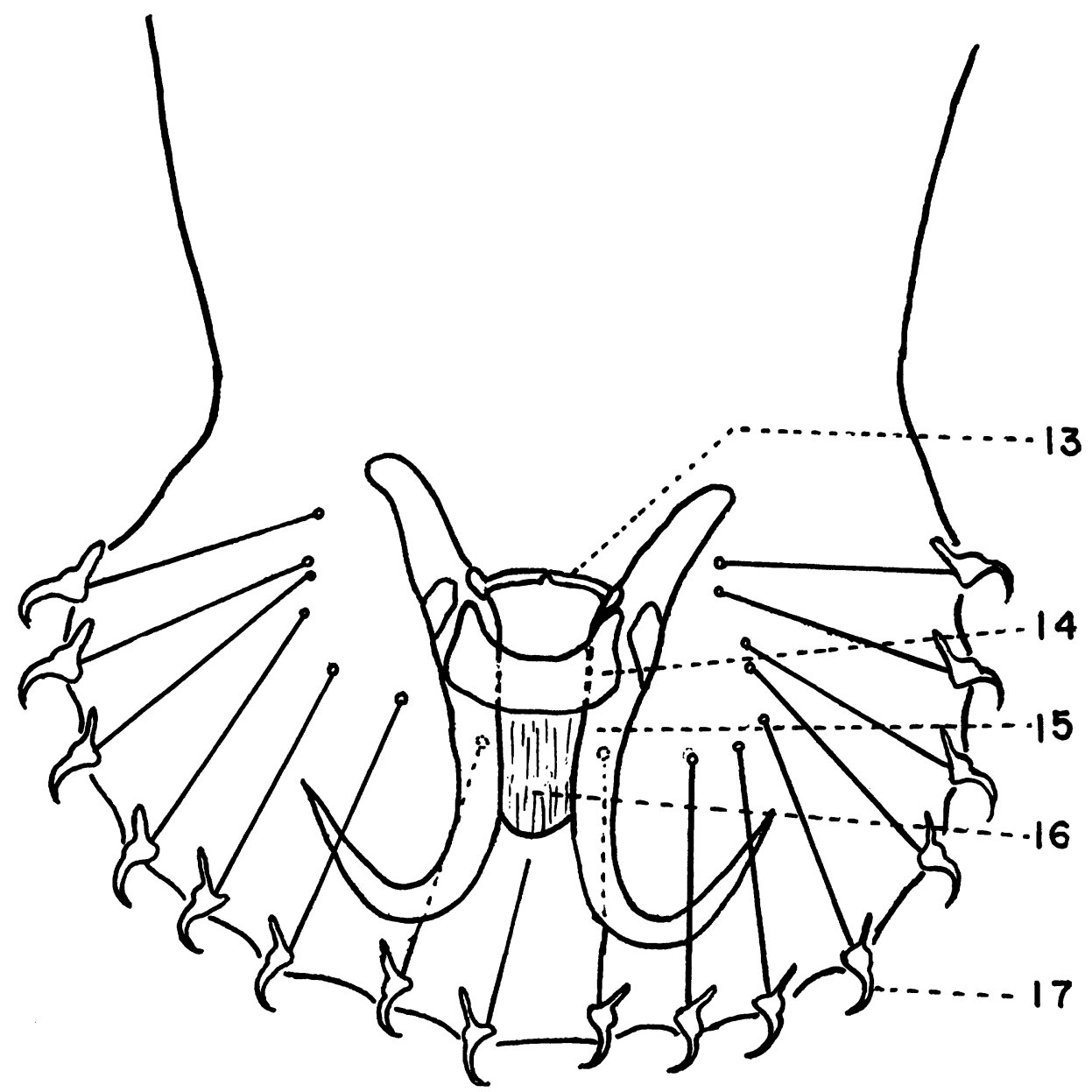

FIgURE 2. Composite drawing of Opisthohaptoral armament of G. eucaliae traced from photomicrographs.

Explanation of Figures: 1, Adhesive organ; 2, Coiled tubule; 3, Connecting tubule; 4, Pharynx; 5. Cephalic gland; 6, Stylet; 7, Cirrus pouch; 8, Embryo; 9, Intestinal crura; 10, Ootype; 11, Ovary; 12, Testis; 13, Dorsal bar; 14, Ventral bar; 15, Anchor; 16, Shield; 17, Marginal hooklet. 
extension of the ventral bar as has been reported for some other species, but appears, instead, to be an independent structure that lies upon the ventral bar dorsally and clamps onto the surface of the anchors. The head organ consists of a pair of antero-lateral, papillate organs which lead into a set of globular vesicles lying just antero-lateral to the pharynx; from this structure connecting tubules extend posteriorly; their exact origin could not be determined. Dorsolateral to the pharynx are 2 other vesicular structures termed "cephalic gland" by Mueller and Van Cleave (1932) and "prostate gland" by Yin and Sproston (1948); in our specimens tubules could be seen connecting these structures to the pharynx-at intervals this "gland" fills with fluid and discharges, like a contractile vacuole, into the pharynx. The bilobed pharynx, 0.037 $(0.034-0.041)$ by $0.038(0.036-0.041)$ leads directly into the intestine which immediately bifurcates into 2 large crura. Testis, $0.018-0.029$ by $0.044-0.068$, bilobed, sometimes gives the appearance of 2 testes, situated at posterior ends of intestinal crura. The cirrus, $0.01-0.014$, has 7 stylets and no large spine. Ovary oval and anterior to the testis. Ootype larger, 0.024, and posterior to ovary. Vitellaria 2 irregular groups of lightly staining bodies lateral to the posterior ends of the intestinal crura (not shown in drawing). Often large embryo in utero with second embryo often contained within first.

Under phase microscopy cells were noticed in the intestinal crura; the worms were crushed with gentle pressure to rupture the intestine and release the cells which were cultured in broth and on a nutrient slant at $4-6^{\circ} \mathrm{C}$. Moderate growths were obtained, which were found to be Gram-positive motile rods and yeast-like mold, but were not otherwise identified. They were a constant intestinal flora of the gyrodactylid.

Host: Eucalia inconstans (Kirtland), Brook Stickleback.

Location: Gills and skin.

Locality: English Coulee, Grand Forks, North Dakota.

Paratype: U. S. National Museum Helm. Coll. No. 55619.

\section{Comparison:}

A brief comparison is made here of those species of Gyrodactylus found in North America. The dorsal bar is straight and narrow with a notch at the midpoint in G. eucaliae. On the other hand the dorsal bar is absent in G. cylindriformis, Mueller and Van Cleave, 1932, and in G. fairporti, Van Cleave, 1921. This new species has a shield with longitudinal striations similar to G. stequrus Mueller 1937, and G. stephanus, Mueller, 1937. However, the cirrus pouch of G. eucaliae is unlike those of $G$. stequrus and $G$. stephanus, both of which have a spine and 8 stylets. The shield lacks striations in G. elegans, Nordmann, 1832, (Mueller, 1936) and the shield is absent in G. medius, Katheriner, 1894, (Van Cleave, 1921). G. spathulatus, Mueller, 1936, has a shield so peculiarly characteristic in its spatula-shape that it can hardly be mistaken for any other known species of Gyrodactylus. G. funduli Hargis, 1955, unlike any of the above, has anchors with truncated roots, and G. prolongis, Hargis, 1955, is the only one which has an unusual skirt-like accessory holdfast on the peduncle.

\section{Pathogenicity:}

Yin and Sproston (1948) found that the fan-tailed goldfish of the black and golden varieties were killed by gyrodactyliasis. Death of the infected fishes was thought to be due ultimately to the hyper-secretion of mucus on the gill surfaces, brought about by the irritation due to the large population of gyrodactylids. A very interesting fact that they mention is the presence of another pathogen. They found an exceedingly heavy infestation of a peritrichous ciliate, probably a species of Trichodina, which was not only browsing on the gill surfaces, but which also fastened itself as an epiparasite on the gyrodactylids.

Van Cleave (1921) also reported fatal gyrodactyliasis of the bullhead, Ameiurus melas, at Fairpoint Biological Station of the U. S. Bureau of Fisheries, Iowa. The fish were dead in less than 24 hours after their removal to a running water aquarium 
in the laboratory. Careful examination revealed no cause other than the presence of small trematodes of the genus Gyrodactylus. He also mentioned a case in which a species of Gyrodactylus was discovered on the gills of the rainbow trout in the New York state hatchery at Cold Springs Harbor, Long Island. In many instances their presence in large numbers caused the gills to become shriveled and functionless. He concluded that especially favorable conditions for heavy general infestation result when fishes are crowded in ponds and pools.

There has been no evidence of irritation or fatality that could incriminate gyrodactylids on Eucalia inconstans except under unusual conditions in aquaria. A Trichodina representative was found also on the stickleback infected with gyrodactylids.

\section{Host Specificity:}

Hargis (1953) gives evidence that a very high degree of host specificity exists among the monogenetic trematodes; this specificity is so marked that it is possible to make a fairly accurate identification of the hosts by an analysis of their ectoparasitic trematodes.

One lot of sticklebacks was kept together with fatheads, Pimephales p. promelas for a period of over 2 months. During the first month the gyrodactylids and the ectoparasitic protozoan, Trichodina sp. were found in abundance on the sticklebacks. After the first month an occasional gyrodactylid could be recovered and toward the end of the second month the fish were usually entirely free of them. The only ectoparasites found on the fatheads during this time were Dactylogyrus sp. and Ergasilus sp. Their disappearance from the natural host suggests an actively acquired immunity which has not heretofore been mentioned in connection with species of Gyrodactylus.

\section{Culture of Gyrodactylus:}

No record could be found of an attempt to culture Gyrodactylus artificially. It was believed that if the period of gestation could be determined their approximate density on the host population could then be predicted. Tissue culture media (Syverton, Scherer, and Elwood, 1954) used to grow cancer cells, was diluted $1: 4$ at $4-6^{\circ} \mathrm{C}$, but no new embryos were produced, although the worms remained alive for a maximum of 1 month. It seemed that the embryo died before the parent died. Normally the embryo can be seen undergoing muscular activity even before birth, but after 2 to 3 weeks of culture in this medium the embryo, even though mature, lost its muscular activity. The medium seemed to lack a factor necessary for parturition. An attempt to induce abortion using acetylcholine and adrenalin was made but this proved to be unsuccessful. Another attempt at culturing the trematode was made by using macerated Eucalia filtered through Berkefeld filters for sterility but this was unsuccessful.

\section{SUM MARY}

1. Gyrodactylus eucaliae n. sp. from the brook stickleback, Eucalia inconstans, is described and compared with 9 other species previously reported from North America.

2. The anchors and marginal hooks have been found to be anisotropic. The anchors, but not the ventral bar, dorsal bar, and the apron are soluble in $16 \% \mathrm{KOH}$. 
3. Placing the fish hosts in $0.5 \%$ nembutal or urethane was found to be the best method of getting mucus-free parasites rapidly.

4. A Gram-positive bacillus and yeast, species unidentified, were found to be constant intestinal organisms in Gyrodactylus eucaliae.

5. Diluted tissue culture medium was successful for maintenance of the worms at $4^{\circ}$ to $6^{\circ} \mathrm{C}$, but not for reproduction. Macerated filtered Eucalia medium was unsuccessful for maintenance and reproduction.

6. The continued decline in intensity of infections on fishes in aquaria suggests the possibility of an actively acquired immunity by the host, Eucalia inconstans.

\section{BIBLIOGRAPHY}

ArCADI, J. A. 1948 Hortega's Silver Carbonate Method Applied to Gill Parasites; with a Note on the Head Organs. Trans. Amer. Micr. Soc. 67: 285-289.

Demke, D. D. 1952 Staining and Mounting Helminths. Stain Techn. 27: 135-139.

Hargis, W. J. 1953 Monogenetic trematodes of Westhampton Lake Fishes. III. Part 2. A Discussion of Host Specificity. Proc. Helm. Soc. Wash. 20: 98-104.

Hoffman, G. L. 1954 Polyvinyl Alcohol-Fixative-Adhesive for Small Helminths and Protozoa. Trans. Amer. Micr. Soc. 73: 328-329.

Mceller, J. F. And Van Cleave, H. J. 1932 Gyrodactylus cylindriformis New Species. Roosevelt Wildlife Annals 3: 74-154.

Syverton, J. T., Scherer, W. F., and Elwood, P. M. 1954 Studies on the Propagation in Vitro of Poliomyelitis Viruses. J. Lab. Clin. Med. 43: 286-302.

Van Cleave, H. J. 1921 Notes on Two Genera of Ectoparasitic Trematodes from Fresh-Water Fishes. J. Parasitol. 8: 33-39.

Wood, E. M. 1956 Urethane as a Carcinogen. Prog. Fish Cult. 18: 135-136.

Yin, Wen-Ying and Sproston, N. G. 1948 Studies on the Monogenetic Trematodes of China: Parts I-V. Sinensia 19: $57-85$. 